\title{
Changes in the localization of MHC class II positive cells in hen ovarian follicles during the processes of follicular growth, postovulatory regression and atresia
}

\author{
A. Barua ${ }^{1}$, H. Michiue ${ }^{1}$ and Y. Yoshimura ${ }^{2 *}$ \\ ${ }^{1}$ Graduate School for International Development and Cooperation, and ${ }^{2}$ Faculty of Applied \\ Biological Science, Hiroshima University, Higashi-Hiroshima 739-8528, Japan
}

The aim of this study was to determine the changes in the population of major histocompatibility complex class II positive $\left(\mathrm{MHC}-\mathrm{II}^{+}\right)$cells in ovarian follicles during the processes of follicular growth, postovulatory regression and follicular atresia in hens. Cryostat sections of ovarian stroma containing cortical follicles, small white follicles, the largest $\left(F_{1}\right)$ and third largest $\left(F_{3}\right)$ preovulatory follicles, postovulatory and atretic follicles of laying hens were prepared. The sections were immunostained for MHC-II molecules using mouse anti-chicken MHC-II monoclonal antibody and positive cells were counted using a computer-assisted image analyser under a light microscope. MHC- $\mathrm{II}^{+}$cells were localized in the theca layer of normally growing follicles including cortical follicles, small white follicles and $F_{3}$ and $F_{1}$ preovulatory

\section{Introduction}

Major histocompatibility complex class II (MHC-II) molecules are cell surface glycoproteins that are found in monocytes, macrophages and activated $\mathrm{B}$ and $\mathrm{T}$ cells (Vainio et al., 1987; Bourlet et al., 1988). An immune response against an antigenic agent requires a series of cellular interactions. One of these events is the processing and presentation of antigens by antigen-presenting cells containing MHC-II molecules (Maccubbin and Schierman, 1986; Vainio et al., 1987). MHC-II molecules present antigens to the helper subset of T cells (CD4 T cells) and, thus, play central roles in the initiation of immune reactions (Benacerraf, 1981; Vainio et al., 1988; Arstila, 1994).

Immunocompetent cells including MHC-II positive (MHC$\mathrm{II}^{+}$) cells in the ovary could play important roles in the protection of ovarian tissues from infection and prevention of disease transmission to eggs. Recently, it was found that MHC$\mathrm{II}^{+}$cells are present in the ovarian stroma and theca layer of cortical follicles (Barua and Yoshimura, 1999). However, it is not known whether these immunocompetent cells play a role in the local modulation of ovarian functions in hens.

*Correspondence.

Email: yyosimu@hiroshima-u.ac.jp follicles, whereas they were found in both the theca and granulosa layers in postovulatory and atretic follicles. The frequency of $\mathrm{MHC}_{-1 \mathrm{II}^{+}}$cells in the theca layer was significantly increased during follicular growth from cortical follicles to $F_{3}$ preovulatory follicles. Although the population of MHC-II+ cells did not differ between $F_{3}$ and $F_{1}$ preovulatory follicles, it increased significantly in postovulatory follicles $(P<0.01)$. The population of MHC$\mathrm{II}^{+}$cells was significantly greater in the theca layer of atretic follicles than in non-atretic follicles $(P<0.01)$. These results indicate that the antigen-presenting function via MHC-II increases in association with follicular growth. A marked increase in MHC- $\mathrm{II}^{+}$cells indicates that these cells may be involved in regression of postovulatory and atretic follicular tissues.
In addition to disease resistance, MHC-II antigens have been reported to be involved in the modulation of ovarian functions, such as regression of corpora lutea (Pate, 1995), degradation of atretic follicular tissues (Fujiwara et al., 1993), premature ovarian failure (Hill and Anderson, 1990) and certain autoimmune disorders (Bottazzo et al., 1983; Coulam and Stern, 1991) in mammals. Chicken MHC-II molecules are similar in structure and function to those of mammals (Vainio et al., 1987; Kaufman, 1999). Therefore, it is possible that chicken MHC-II molecules, as reported in mammals, play important roles not only in protection from infection but also in regulation of follicular function. However, there are no reports about whether the localization of $\mathrm{MHC}-\mathrm{II}^{+}$cells changes with respect to follicular growth, postovulatory regression and atresia of follicles. The aim of the present study was to determine

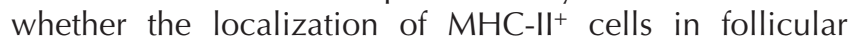
tissues changes during follicular development, postovulatory regression and atresia.

\section{Materials and Methods}

\section{Birds}

White Leghorn laying hens aged approximately 450 days and laying more than five eggs in a sequence were used 
$(n=5)$. The hens were kept in individual cages under a light regimen of $14 \mathrm{~h}$ light: $10 \mathrm{~h}$ dark, and feed and water were available ad libitum.

\section{Tissue preparation}

Birds were killed by decapitation just after oviposition (approximately $30 \mathrm{~min}$ before the expected time of ovulation) (Warren and Scott, 1935). Ovarian stroma in which cortical follicles were embedded, normal and atretic small white follicles approximately $3-4 \mathrm{~mm}$ in diameter, the third largest and largest preovulatory follicles $\left(\mathrm{F}_{3}\right.$ and $\mathrm{F}_{1}$, respectively), and postovulatory follicles of day 1 and day 3 after ovulation were collected. Atretic small white follicles with deformed condition were also collected. All tissues were embedded in OCT compound and snap frozen in a mixture of isopentane and solid carbon dioxide. Cryostat sections ( $15 \mu \mathrm{m}$ thickness) were prepared and air dried on slides treated with 3-aminopropyl-triethoxysilane as described by Van Prooijen-Knegt et al. (1982). The sections were then fixed with cold acetone and methanol for $10 \mathrm{~min}$ each.

\section{Antibodies}

Mouse monoclonal anti-chicken MHC-II antibody (Veromaa et al., 1988) was used as the primary antibody. Immunodetection kit S-HRP (Seikagakukogyo Co, Tokyo) was used for detection of immunoprecipitates of primary antibodies.

\section{Immunostaining}

Sections were washed with PBS for $15 \mathrm{~min}(3 \times 5 \mathrm{~min})$ and incubated with $1 \%(\mathrm{v} / \mathrm{v})$ normal goat serum for $15 \mathrm{~min}$ to block non-specific binding of antibodies. Sections were incubated overnight with mouse anti-chicken MHC-II antibody diluted with PBS containing $0.5 \%(\mathrm{w} / \mathrm{v}) \mathrm{BSA}$ at a dilution of 1:100, followed by washing with PBS for 15 min $(3 \times 5 \mathrm{~min})$. Immunoreactions of the first antibody on the sections were detected by S-HRP immunostaining kit according to the manufacturer's instructions. In brief, the sections were incubated with the biotinylated secondary antibody and with avidin-biotin-peroxidase complex for $1 \mathrm{~h}$ each. Finally, immunoprecipitates were visualized by incubation with a mixture of $0.02 \%(\mathrm{w} / \mathrm{v}) 3^{\prime}, 3^{\prime}-$ diaminobenzidine-tetrahydrochloride (Sigma, St Louis, $\mathrm{MO})$ and $0.001 \%(\mathrm{w} / \mathrm{v}) \mathrm{H}_{2} \mathrm{O}_{2}$ in 0.05 mol Tris- $\mathrm{HCl} \mathrm{I-1}(\mathrm{pH}$ 7.6). The sections were counterstained with haematoxylin after immunostaining, dehydrated and covered. Control staining was carried out simultaneously in which the first antibody was replaced with normal mouse IgG. No specific staining was found in the control slides.

\section{Counting of $\mathrm{MHC}-\mathrm{II}^{+}$cells}

The sections were examined under a light microscope with image analysis software (Image-Pro Plus, Media
Cybernetics, Silver Spring, MD). The numbers of immunopositive cells were obtained by observing three different regions of the theca (approximately $0.5-3.0 \times 10^{4} \mu \mathrm{m}^{2}$ tissue) as described by Barua et al. (1998a). The number of cells was calculated to be the number of cells in $1 \times 10^{4} \mu \mathrm{m}^{2}$ tissue. The mean of the three counts was expressed as the number of cells in $1 \times 10^{4} \mu \mathrm{m}^{2}$ area in one tissue of a bird.

\section{Statistical analysis}

The significance of differences in the number of positive cells in $1 \times 10^{4} \mu \mathrm{m}^{2}$ area was determined by one-way ANOVA (Snedecor and Cochran, 1967), followed by Duncan's multiple range test (Duncan, 1955). Student's $t$ tests were used for the analysis of positive cells in atretic follicles and differences between the means were considered significant at $P<0.01$.

\section{Results}

Changes in the frequency of $\mathrm{MHC}-\mathrm{II}^{+}$cells during follicular growth and postovulatory regression

The cortical follicles were embedded in the ovarian stroma and the small white follicles and $F_{3}$ and $F_{1}$ preovulatory follicles protruded from the ovarian surface. The wall of cortical follicles, small white follicles and $F_{3}$ and $\mathrm{F}_{1}$ preovulatory follicles consisted of the theca and granulosa layers. In the day 1 postovulatory follicles the theca layer became contracted with partial detachment of granulosa layer and in the day 3 postovulatory follicles the theca and granulosa layers became more regressed. MHC- $-\mathrm{Il}^{+}$cells were localized in the theca layer but not in the granulosa layer of normal cortical follicles, small white follicles and $F_{3}$ and $F_{1}$ preovulatory follicles, whereas they were localized in both the theca and granulosa layers in postovulatory follicles (Fig. $1 \mathrm{a}-\mathrm{f}$ ). Some thecal fibroblastlike cells in these prehierarchical and hierarchical follicles also stained positive for MHC-II. These results were observed equally in five repeated observations. The frequency of $\mathrm{MHC}-\mathrm{Il}^{+}$cells in the theca layer of normal cortical follicles was 4.5 cells in $1 \times 10^{4} \mu \mathrm{m}^{2}$ and it increased significantly to 9.9 cells in $1 \times 10^{4} \mu \mathrm{m}^{2}$ in small white follicles $(P<0.01)$ (Fig. 2). The frequency of MHC-II+ cells increased significantly in the theca layer of $F_{3}$ and $F_{1}$ preovulatory follicles compared with cortical follicles and small white follicles $(P<0.01)$. The population of $\mathrm{MHC}-\mathrm{II}^{+}$ cells in the theca layer of $\mathrm{F}_{3}$ preovulatory follicles was 15.3 cells in $1 \times 10^{4} \mu \mathrm{m}^{2}$ and no significant difference was observed in the frequency of $\mathrm{MHC}-\mathrm{II}^{+}$cells between $\mathrm{F}_{3}$ and $\mathrm{F}_{1}$ preovulatory follicles. The frequency of $\mathrm{MHC}-\mathrm{II}^{+}$cells in the theca layer of postovulatory follicles was significantly greater than in preovulatory follicles. However, no significant difference was observed in the population of MHC-II+ cells between day 1 and day 3 postovulatory follicles (Fig. 2). 

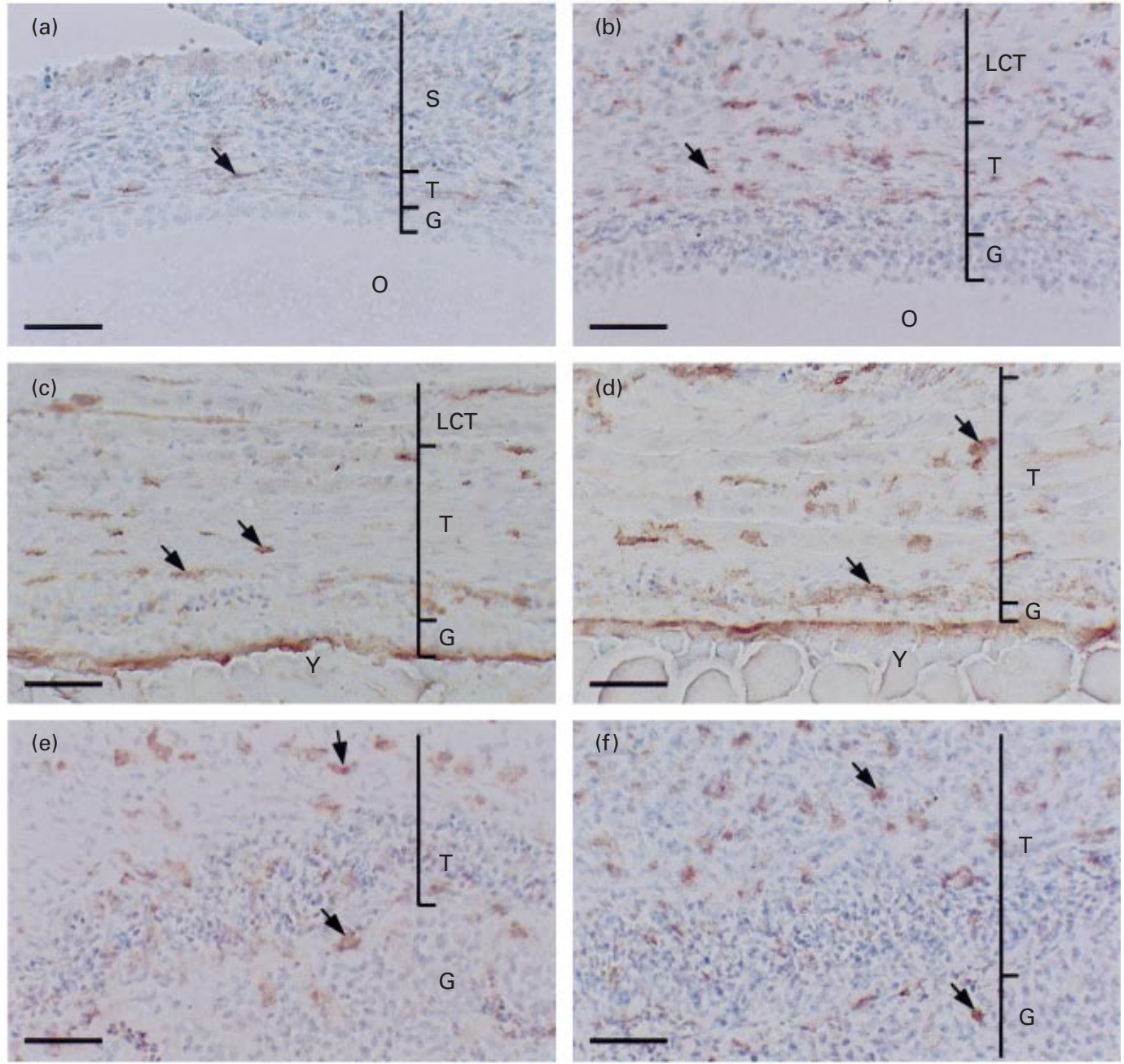

Fig. 1. Sections of chicken ovarian follicles immunostained for major histocompatibility complex class II (MHC-II). (a) Ovarian stroma containing cortical follicle. (b) Small white follicle. (c) Third largest preovulatory follicle. (d) Largest preovulatory follicle. (e) Postovulatory follicle on day 1 after ovulation. (f) Postovulatory follicle on day 3 after ovulation. Thecal fibroblast-like cells stained positive for MHC-II in all follicles. In the granulosa layer, positive cells are seen in the postovulatory follicles only. Arrows indicate examples of MHC class II positive cells. G: granulosa layer; LCT: loose connective tissue coat; O: oocyte; S: ovarian stroma; $\mathrm{T}$ : theca layer; Y: yolk. Scale bars represent $50 \mu \mathrm{m}$.

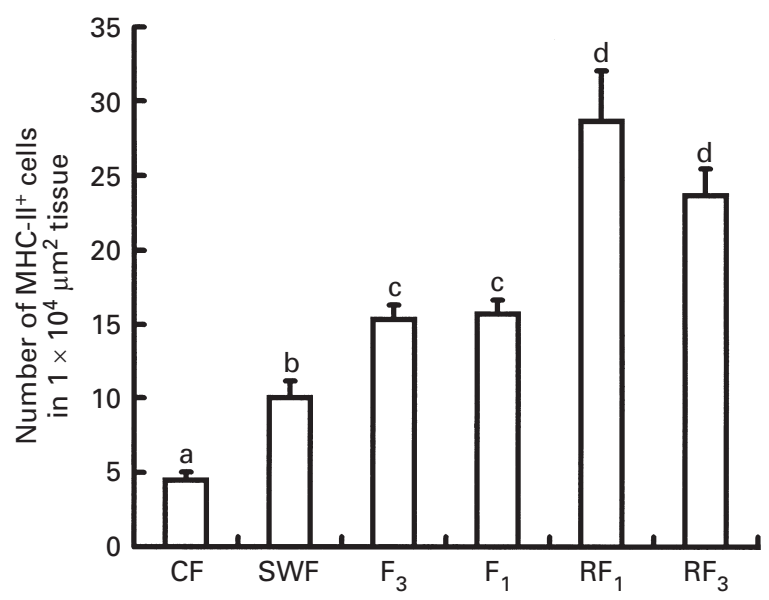

\section{Changes in the frequency of $\mathrm{MHC}-\mathrm{II}^{+}$cells during follicular atresia}

Atretic cortical follicles embedded in the stroma were observed occasionally in the ovarian sections, whereas atretic small white follicles protruded from the ovarian surface. Granulosa cells were detached from the theca layer

Fig. 2. Changes in the population of major histocompatibility complex class II positive (MHC- $\left.\mathrm{II}^{+}\right)$cells in ovarian follicles during follicular growth and postovulatory regression. CF: cortical follicle; SWF: small white follicle; $F_{3}$ : third largest preovulatory follicle; $F_{1}$ : largest preovulatory follicle; $\mathrm{RF}_{1}$ : postovulatory follicle on day 1 after ovulation; $\mathrm{RF}_{3}$ : postovulatory follicle on day 3 after ovulation. Values are mean $\pm \operatorname{SEM}(n=5$ birds in each group). abcd Columns with different letters are significantly different $(P<0.01)$. 

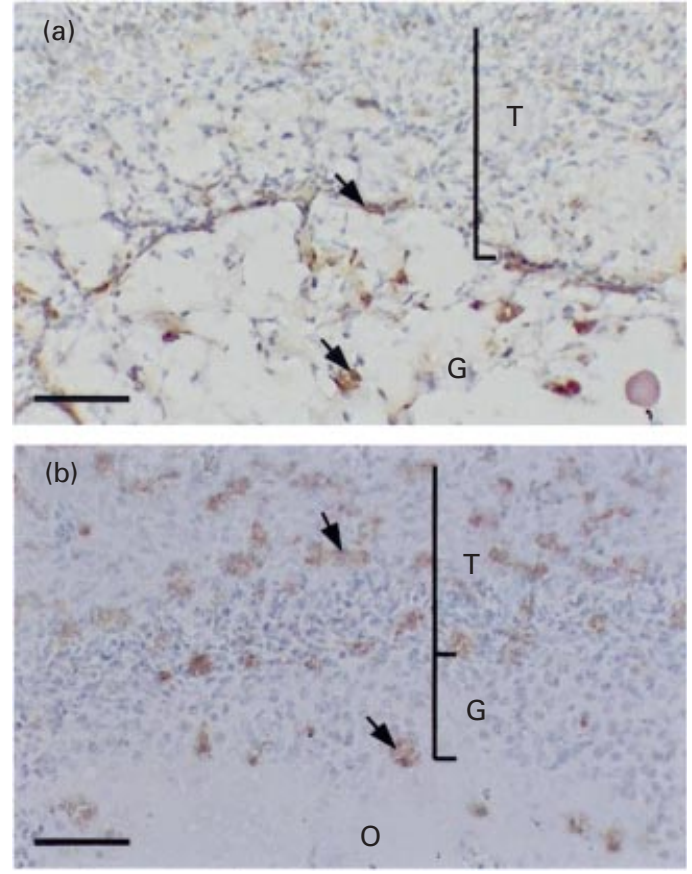

Fig. 3. Sections of atretic follicles of laying hens immunostained for major histocompatibility complex class II $\left(\mathrm{MHC}-\mathrm{II}^{+}\right)$positive cells. (a) Atretic cortical follicle and (b) atretic small white follicle. The granulosa layers are disintegrated, detached from the thecal layer and invaded into the follicular lumen in both categories of atretic follicle. MHC-II+ cells are observed in the granulosa and theca layers as well as in the follicular lumen. O: oocyte; G: granulosa layer/cell; T: theca layer. Arrows indicate examples of MHC-II+ cells. Scale bars represent $50 \mu \mathrm{m}$.

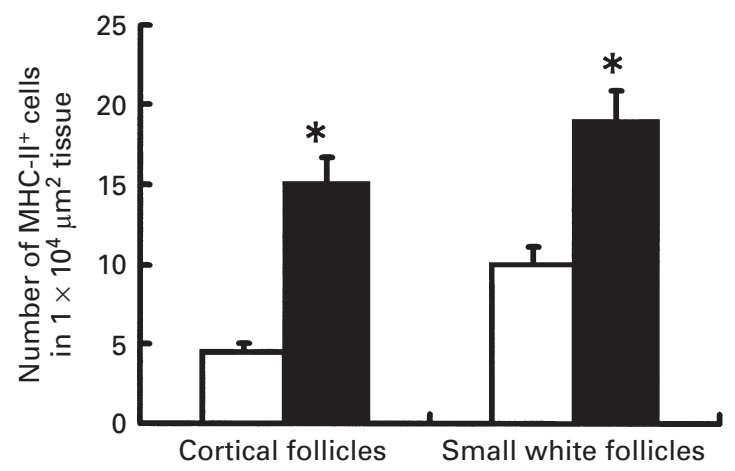

Fig. 4. Frequency of major histocompatibility complex class II positive $\left(\mathrm{MHC}-\mathrm{II}^{+}\right)$cells in normal $(\square)$ and atretic $(\square)$ follicles in chickens. Values are mean $\pm \operatorname{SEM}(n=5$ birds in each group). *Significantly different from corresponding normal value $(P<0.01)$.

and invaded the follicular lumen in both categories of atretic follicles. MHC-II+ cells were found in the granulosa and theca layers as well as in the follicular lumen of atretic follicles (Fig. 3a,b). The frequencies of MHC-II+ cells in the theca layer were significantly greater in both the atretic cortical follicles and small white follicles (approximately 15 cells and 19 cells in $1 \times 10^{4} \mu \mathrm{m}^{2}$, respectively) compared with normal follicles $(P<0.01)$ (Fig. 4$)$.

\section{Discussion}

This is the first report in which the changes in the localization of $\mathrm{MHC}-\mathrm{II}^{+}$cells in hen ovarian follicles have been examined with respect to follicular events. The major findings were: (i) $\mathrm{MHC}-\mathrm{Il}^{+}$cells were localized in the theca layer of normally growing follicles, but in both the theca and granulosa layers of postovulatory and atretic follicles; (ii) the frequency of thecal $\mathrm{MHC}-\mathrm{II}^{+}$cells was significantly increased in association with follicular growth from cortical follicles to $F_{3}$ preovulatory follicles; however, no difference in their frequencies was observed between $F_{3}$ and $F_{1}$ preovulatory follicles; and (iii) an increased population of $\mathrm{MHC}-\mathrm{Il}^{+}$cells was observed in the theca layers of postovulatory and atretic follicles.

In a previous study, we reported the presence of $\mathrm{MHC}-\mathrm{II}^{+}$ cells in some of the thecal fibroblast-like cells in the cortical follicles (Barua and Yoshimura, 1999). In the present study, it was found that some fibroblast-like cells of the theca layer expressed MHC-II antigen not only in prehierarchical but also in hierarchical follicles. Carbon particles that were injected i.v. into laying hens were internalized by the fibroblasts in the theca interna of preovulatory follicles, indicating that these cells may be able to phagocytose foreign antigens (Yoshimura and Okamoto, 1998). Therefore, the antigen presenting ability of the thecal fibroblast-like cells may play a significant role in the protection of growing yolk from pathogenic organisms passing through the follicular wall.

Presl and Bukovsky (1986) identified MHC-II+ cells in the theca layer of normal growing follicles in rats and suggested that these immunocompetent cells might be involved in normal follicular development. In the present study, the population of ${\mathrm{MHC}-\mathrm{II}^{+}}$cells increased during follicular growth from cortical follicles to $F_{3}$ preovulatory follicles.

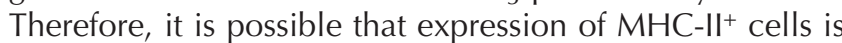
enhanced with follicular development in both chickens and mammals. In a previous study, we observed that treatment of immature birds with oestrogen enhanced expression of MHC-II antigens in the ovarian stroma and theca of cortical follicles (Barua and Yoshimura, 1999). Oestrogen is produced by aromatase cells in the theca externa of smaller follicles and there is a linear decrease in oestrogen production with the lowest production in $\mathrm{F}_{1}$ preovulatory follicles (Bahr et al., 1983; Bahr, 1991; Johnson, 1996). Therefore, oestrogen may be one of the local regulators to increase $\mathrm{MHC}-\mathrm{II}^{+}$cell frequency in the theca of growing smaller yellow follicles. During the later stage of follicular growth, for example from $F_{3}$ to $F_{1}$ preovulatory follicles, oestrogen production is low and the thecal MHC-II+ cell frequency is not changed significantly.

The finding that there was no significant difference in the thecal MHC-II+ cell population between $\mathrm{F}_{3}$ and $\mathrm{F}_{1}$ preovulatory follicles collected approximately $30 \mathrm{~min}$ before ovulation indicates that there is no increase in $\mathrm{MHC}-\mathrm{II}^{+}$cells of these follicles with ovulation. In the present study, the number of thecal MHC-II+ cells in the day 1 and day 3 
postovulatory follicles was greater than in $F_{1}$ and $F_{3}$ preovulatory follicles, and $\mathrm{MHC}-\mathrm{II}^{+}$cells appeared in the granulosa layer of postovulatory follicles but not preovulatory follicles. In mammals, there are reports that MHC$\mathrm{II}^{+}$antigen is expressed in the cells of corpora lutea that had undergone regression (Kenny et al., 1991; Pate, 1995). Thus, it may be proposed that MHC-II+ cells play a role in the regression of postovulatory follicles in hen ovaries.

In atretic follicles, MHC-II+ cells were localized in both the granulosa and theca layers, and their frequencies in the theca were significantly greater than in normal follicles. MHC-II protein was reported to be present on granulosa cells of atretic cortical follicles in human ovaries (Fujiwara et al., 1993). Previously, we reported that macrophages, which express $\mathrm{MHC}-\mathrm{II}^{+}$, infiltrate the atretic follicles (Barua et al., 1998b). These macrophages were localized in the thecal connective tissue and granulosa layer or follicular lumen. The region where $\mathrm{MHC}-\mathrm{II}^{+}$cells were localized in the atretic follicles was identical to that in which macrophages were found. Therefore, many of the MHC- $\mathrm{II}^{+}$ cells in the theca and granulosa layers are likely to be macrophages, and they may play a role in the removal of atretic bodies, as suggested in our previous study (Barua et al., 1998b).

In conclusion, it was found that the population of MHC-II+ cells increased with follicular growth as well as postovulatory regression and follicular atresia. These cells may play significant roles not only in the removal of infectious or antigenic agents in the growing follicles but also in tissue regression by apoptosis of postovulatory and atretic follicles.

The authors would like to thank O. Vainio, Department of Medical Microbiology, University of Turku, Finland, for his kind donation of antibody to chicken MHC class II. This work was supported by Grants-in Aid for Scientific Research from the Ministry of Education, Science and Culture, Japan (No. 12660257) to $\mathrm{Y}$. Yoshimura.

\section{References}

Arstila TP (1994) Central role of CD4 ${ }^{+} \mathrm{T}$ cells in avian immune response Poultry Science 73 1019-1026

Bahr JM (1991) The chicken ovary as a model of follicular development Seminars in Reproductive Endocrinology 9 352-359

Bahr JM, Wang SC, Huang MY and Calvo FO (1983) Steroid concentrations in isolated theca and granulosa layers of preovulatory follicles during the ovulatory cycle of the domestic hen Biology of Reproduction 29 326-334

Barua A and Yoshimura Y (1999) Immunolocalization of MHC- II $^{+}$cells in the ovary of immature, young laying and old laying hens Gallus domesticus. Journal of Reproduction and Fertility 116 385-389

Barua A, Yoshimura Y and Tamura T (1998a) Localization of macrophages in the ovarian follicles during the follicular growth and postovulatory regression in chicken, Gallus domesticus. Poultry Science 77 1417-1421
Barua A, Yoshimura Y and Tamura T (1998b) The effects of age and sex steroids on the macrophage population in the ovary of the chicken, Gallus domesticus. Journal of Reproduction and Fertility 114 253-258

Benacerraf B (1981) Role of MHC gene products in immune regulation Science 212 1129-1138

Bottazzo GF, Pujol-Borrel R, Hanafusa T and Fieldman R (1983) Role of aberrant HLA-DR expression and antigen presentation in the induction of endocrine autoimmunity Lancet ii 1115-1118

Bourlet Y, Behar G, Guillemot F, Frechin N, Billaut A and Chausse A (1988) Isolation of chicken major histocompatibility complex class II (B-L) chain sequences: comparison with mammalian $B$ chains and expression in lymphoid organs European Molecular Biology Journal 7 1031-1039

Coulam CB and Stern JJ (1991) Immunology of ovarian failure American Journal of Reproductive Immunology 25 169-174

Duncan B (1955) Multiple range and $\mathrm{F}$ test Biometrics 11 1-42

Fujiwara H, Ueda M, Imai K et al. (1993) Human leukocyte antigen-DR is a differentiation antigen for human granulosa cells Biology of Reproduction 49 705-715

Hill JA and Anderson DJ (1990) Evidence for the existence and significance of immune cells in male and female reproductive tissues Immunology and Allergy Clinics of North America 10 1-2

Johnson AL (1996) The avian ovarian hierarchy: a balance between follicle differentiation and atresia Poultry and Avian Biology Reviews $799-110$

Kaufman J (1999) Co-evolving genes in MHC haplotypes: the "rule" for nonmammalian vertebrates? Immunogenetics 50 228-236

Kenny N, Herman JR, Barisas BG and Roess DA (1991) Flow cytometric analysis of class I and II MHC antigens on ovine luteal cell types. In Signaling Mechanisms and Gene Expression in the Ovary pp 467-472 Ed G. Gibori. Springer-Verlag, New York

Maccubbin DL and Schierman LW (1986) MHC-restricted cytotoxic response of chicken $\mathrm{T}$ cells: expression, augmentation and clonal characteristics Journal of Immunology 136 12-16

Pate JL (1995) Involvement of immature cells in regulation of ovarian functions Journal of Reproduction and Fertility Supplement 49 365-377

Presl J and Bukovsky A (1986) Role of Thy-1+ and la+ cells in ovarian function Biology of Reproduction 34 159-169

Snedecor GW and Cochran WG (1967) One-way classifications. Analysis of variance. In Statistical Methods pp 258-298 Eds GW Snedecor and WG Cochran. lowa State University Press, Ames, IA

Vainio O, Toivanen P and Toivanen A (1987) Major histocompatibility complex and cell cooperation Poultry Science 66 795-801

Vainio O, Veromaa T, Eerola E, Toivanen P and Ratcligge MJ (1988) Antigen-presenting cell-T cell interaction in the chicken is MHC class II antigen restricted Poultry Science 140 2864-2868

Van Prooijen-knegt AC, Raaf AK, Van Der Berg MJM, Vrolijk J and Van Der Ploeg (1982) Spreading and staining of human metaphage chromosomes on aminoalkyl-silane-treated glass slides Histochemical Journal $14333-344$

Veromaa T, Vainio O, Jalkanen S, Eerrola E, Cranfors $\mathrm{K}$ and Toivanen $\mathbf{P}$ (1988) Expression of B-L and Bu-1 antigens in chickens bursectomized at $60 \mathrm{~h}$ of incubation European Journal of Immunology 18 225-230

Warren DC and Scott HM (1935) Time factor in poultry production Poultry Science 14 195-207

Yoshimura Y and Okamoto T (1998) Phagocytosis of carbon particles by theca interna fibroblasts in hen ovary Japanese Poultry Science $\mathbf{3 5}$ $314-318$

Received 25 September 2000.

First decision 22 November 2000.

Accepted 21 February 2001. 